\title{
The contribution of chestnut coppice forests on slope stability in abandoned territory: a case study
}

\author{
Chiara Bassanelli, Gian Battista Bischetti, Enrico Antonio Chiaradia, Lorenzo Rossi \\ Chiara Vergani
}

DiSAA - Università degli Studi di Milano, Italy

\begin{abstract}
Sweet chestnut has been for many centuries fundamental for the Italian mountainous economies, where this kind of forest was traditionally managed in short rotation to rapidly produce wood biomass. Due to the social and economic changes, which made such management scheme unprofitable especially on the steep and remote slopes, such practice has been mainly abandoned and most of chestnut forests became over-aged and very dense, causing an increase of localized slope instability. In this work the effect of over-aged chestnut coppice forests on shallow landslides was analysed by evaluating and comparing mechanical contribution to soil shear strength provided by root systems in differently managed chestnut stands. The study area is located in Valcuvia (Lombardy Prealps) where three different stands, one managed and the others abandoned (over 40 year aged), established on cohesionless slopes (quaternary moraine deposits) were chosen having care to select homogeneous conditions in terms of substrate, aspect and elevation. As slope steepness strongly affects forestry practices and steeper stands are more frequently abandoned, the considered stands have different terrain inclination, $30-35^{\circ}$ in abandoned stands and $13^{\circ}$ in the managed one. Slope stability of the three sites was evaluated by applying the infinite slope approach accounting for additional root cohesion and tree surcharge. Additional root cohesion was estimated through the Fiber Boundle Model approach by collecting roots in the field and measuring their resistance in laboratory, and by measuring root diameter and density distri-
\end{abstract}

Correspondence: Gian Battista Bischetti, DiSAA via Celoria 2 , 20133 Milano, Italy.

Tel. +39.0250316904 - Fax +39.0250316911. E-mail bischetti@unimi.it

Key words: root cohesion, slope stability, sweet chestnut.

Contributions: the authors contributed equally.

Conflict of interests: the authors declare no potential conflict of interests Funding: the work was supported by Regione Lombardia - DG Agricoltura under "Programma Regionale di Ricerca in campo agricolo - Piano della ricerca 2004" - "Progetto Cedui e Dissesto Idrogeologico" ProCeDI.

(C) Copyright C. Bassanelli et al., 2013

Licensee PAGEPress, Italy

Journal of Agricultural Engineering 2013; XLIV(s2):e13

doi:10.4081/jae.2013.s2.e13

This article is distributed under the terms of the Creative Commons Attribution Noncommercial License (by-nc 3.0) which permits any noncommercial use, distribution, and reproduction in any medium, provided the original author(s) and source are credited. bution with depth by the wall technique method.

The results, as expected, showed that over-aging does not affect root mechanical properties, whereas it significantly affects root distribution within the soil. In terms of slope stability, when steepness exceeds $35^{\circ}$, instability phenomena can be triggered by high level of soil saturation in the case of over-aged forests, whereas for less extreme cases chestnut forests, although over-aged, are able and fundamental to guarantee safe conditions.

\section{Introduction}

The role of forests in contrasting many natural hazards is well established from ages (e.g. Motta and Haudemand 2000), especially when slope stability is the considered threat (e.g. Sakals et al. 2006). In the last decades a great number of studies have been carried out aiming to explain and quantify the effect of vegetation on slope stability (e.g. Bischetti et al. 2009; Schwarz et al., 2010) and to model the soil reinforcement by roots (e.g. Wu, 2013).

Considerable less attention has been dedicated to the role of forest management on slope stability (e.g. Sidle, 1991), although a great part of forests around the world are now managed and nearly all the European and Italian forests have been managed from centuries. Among the most anthropised forests in the Alps and in the Apennines, sweet chestnut represents one of the most important and common case. Chestnut, in fact, for a long time has been the basis for many traditional mountain economies, which used it for fire, food, livestock feeding, manufacturing of daily tools, etc. (Del Favero, 2002). As chestnut has a naturally tendency to develop from the same stool several adventitious shoots characterised by a rapid growth, a common practice adopted to maximize the biomass increase is coppicing with a short rotation length $(<20$ years) and such a practice can be considered as the standard management scheme for chestnut in Italy.

Things have changed from the second half of XX century when the great socio-economic transformation which occurred in mountain society structure led to abandon many forests (Del Favero, 2002; Vogt et al., 2006). Chestnut forests passed this from being over-managed, to be under-managed with a consequent over-aging of shoots and stools (several times the usual rotation length).

In such a situation a central question raises regarding the capability of over-aged coppiced sweet chestnut forests to guarantee the slope stability, especially in the many cases where steepness is high and soils are cohesionless. In many areas of Italian Alps and Prealps, in fact, demographic increase forced people to plant sweet chestnut also on very steep slopes, which were the first to be abandoned when the economic situation improved.

The aim of this paper is to improve our knowledge on the role of over-aged sweet chestnut forest in hillslopes stability by quantifying the contribution of roots in terms of additional cohesion. Three sites 
were taken in Valcuvia (Varese, Italy) as a case study of over-aged sweet chestnut forests on cohesionless and steep terrains, that is a typical conditions of many hillslopes of Lombardy.

\section{Material and methods}

\section{Slope stability model}

In the case of shallow landsliding phenomena triggered by intense rainstorms, the infinite slope approach represents a standard among the different geotechnical models that can be adopted (Sidle and Ochiai, 2006). As all approaches referring to General Limit Equilibrium principle, the infinite slope method expresses the stability of hillslopes in terms of factor of safety, FoS, representing the ratio between stabilizing and destabilizing forces.

Under this approach, FoS for forest hillslopes can be calculated as (Hammond et al., 1992):

$$
F O S=\frac{c_{r}+c_{s}+\cos ^{2} \alpha\left[q 0+\gamma\left(D-D_{w}\right)+\left(\gamma_{\text {sat }}-\gamma_{w}\right) D_{w}\right] \tan \phi}{\sin \alpha \cos \alpha\left[q 0+\gamma\left(D-D_{w}\right) \gamma_{\text {sut }} D_{w}\right]}
$$

where $\alpha$ is the angle of ground surface $\left(^{\circ}\right), D$ is soil thickness (m), $D_{w}$ is saturated soil thickness $(\mathrm{m}), c_{r}$ is tree root reinforcement expressed as cohesion $\left(\mathrm{N} / \mathrm{m}^{2}\right), q_{0}$ is tree surcharge $\left(\mathrm{N} / \mathrm{m}^{2}\right), c_{s}$ is soil cohesion $\left(\mathrm{N} / \mathrm{m}^{2}\right), \varphi$ is the effective friction angle $\left({ }^{\circ}\right), \gamma$ is moist soil unit weight $\left(\mathrm{kg} / \mathrm{m}^{3}\right), \gamma_{\text {sat }}$ is saturated soil unit weight $\left(\mathrm{kg} / \mathrm{m}^{3}\right)$ and $\gamma_{d}$ is water unit weight $\left(\mathrm{kg} / \mathrm{m}^{3}\right)$. In equation 1 the effect of vegetation is fundamentally accounted for by means of the additional root cohesion and the tree surcharge values (besides hydrological control which reflects on $D_{w}$ ). Estimation of $c_{r}$, that is recognized as playing a key role (Wu et al., 1979; Pollen and Simon, 2005), as a consequence, has been the object of a great number of studies in the last years. The most commonly adopted models for $c_{r}$ estimation refer to the Wu (1976) and Waldron (1977) model, the Fiber Bundle Model (FBM; Pollen and Simon, 2005) and the Root Bundle Model (Schwarz et al., 2010). In the present paper the FBM model has been adopted under the static fiber bundle approach and equal load sharing, as it has been proven to provide safer values (Ji et al, 2010).

FBM basically requires as input parameters the number of roots of different size that are present at different depth and their tensile resistance. According to the literature (e.g. Bischetti et al., 2009; Genet et al., 2010), only roots in the range 1-10 mm have been considered.

The infinite slope model is generally solved considering a shear plane parallel to topographic surface, but in the case of shallow landslides in forest hillsopes also the vertical shear surfaces is considered as resistant and $c_{r}$ is estimated accounting the roots crossing both the vertical and basal planes (see e.g. Roering et al., 2003).

\section{Study area}

The sites where studies have been conducted are located within the boundary of Comunità Montana Valli del Verbano (Figure 1), which is representative of a larger area in Lombardy and in the Prealps where a lot of over-aged coppice chestnut forests established on very steep cohesionless slopes. Within the study area, have been identified three different hillslopes covered by the same chestnut forest type, classified as "Castagneto delle cerchie moreniche occidentali" (Del Favero, 2002), but with different characteristics: A) over-aged coppice chestnut on a hollow topography; B) managed coppice chestnut (approximately 25 years old) and C) over-aged chestnut coppice on a nose topography (Figure 2).
The three sites are homogenous in terms of geology, aspect and elevation, but different in terms of steepness. As inclination strongly affect forest practices, in fact, all managed coppice forests are now limited to gentle and easily accessible slopes. According to USCS (Casagrande, 1948) soil in all sites has been classified as SM "silty sand, sand-silt mixture", and according to the literature and previous studies in similar areas (Bischetti et al., 2004), geotechnical properties have been estimated in a safely perspective as $c^{\prime}=0$ and $\phi^{\prime}=27^{\circ}$. The characteristics of the three sites are reported in Table 1.

Table 1. Site characteristic.

\begin{tabular}{lccc} 
Site & Site A & Site B & Site C \\
Number of trenches & 2 & 2 & 2 \\
Elevation(m a.s.l.) & 600 & 580 & 595 \\
\hline Average inclination $\left(^{\circ}\right.$ ) & 35 & 13 & 30 \\
Average trees diameter (cm) & 24,23 & 21,46 & 17,1 \\
\hline Distance between stools (m) & 3,85 & 4,19 & 5,8 \\
Average trees hight (m) & 14,58 & 11,68 & 12,51 \\
\hline Basal area (m2/ha) & 50,87 & 47,08 & 62,41 \\
Live/dead & $35 / 43$ & $54 / 38$ & $68 / 124$ \\
\hline Management & Over-aged coppice & Managed coppice & Over-aged coppice \\
Topography & Concave & Convex & Convex \\
\hline Soil depth (m) & 0,8 & 0,5 & 0,9 \\
\hline
\end{tabular}

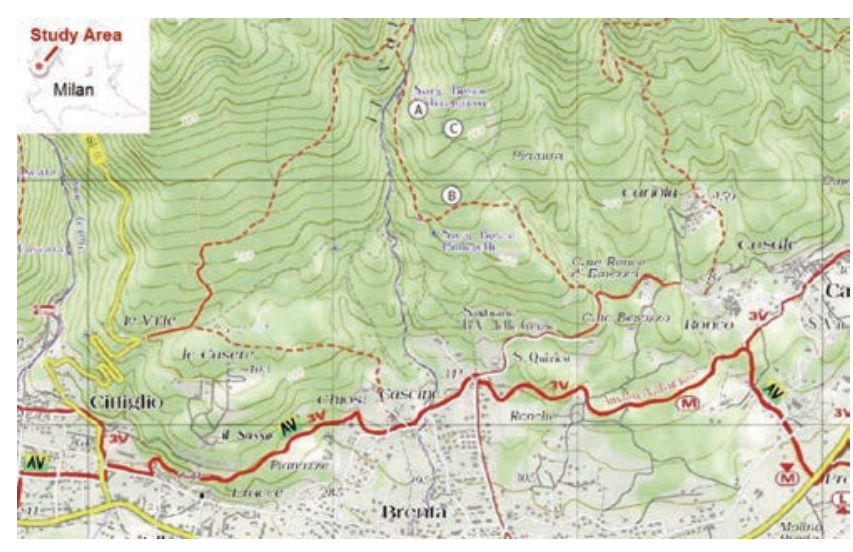

Figure 1. Study area map and location of experimental sites.

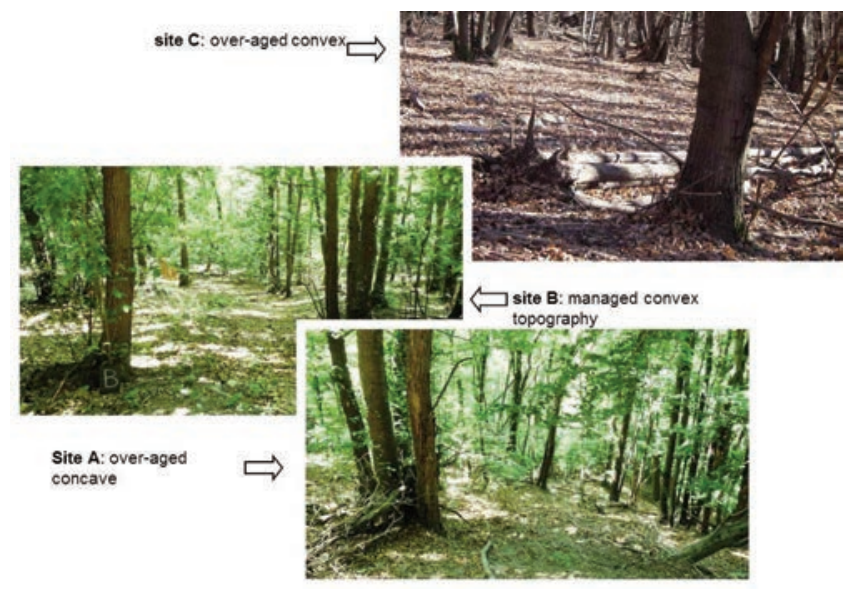

Figure 2. The investigated sites A) over-aged chestnut on hollow, B) managed chestnut and $C$ ) over-aged chestnut on nose. 
In each site two trenches were dug to the parental material and until roots were no more present, in all cases trenches were located in the middle of a group of stools where the effect of roots is likely to be the lowest.

\section{Root tensile tests}

Roots for tensile resistance tests were collected by digging pits in the middle between adjacent stools, having care to do not damage them and sampling the full diameter range between 1 and $10 \mathrm{~mm}$. Samples were preserved to deterioration maintaining roots in a $15 \%$ alcohol solution (Meyer and Gottsche, 1970; Bischetti et al., 2003) until tensile tests were carried out.

Tensile test were performed by a device consisting of a strain apparatus (test speed $10 \mathrm{~mm} / \mathrm{min}$ ) controlled by an electrical motor, equipped with a load cell (F.S. $500 \mathrm{~N}$, accuracy $0.1 \%$ F.S.) and special clamping devices able to avoid root damage at the clamping points (see Bischetti et al., 2009 for details). Only specimens that broke near the middle of the roots between clamps were considered valid. Root size was estimated as the average of three values taken with an electronic caliper at three points near the section of the potential breaking (Abdi et al., 2010; Vergani et al., 2012).

\section{Root density measures}

Root density was measured at each dug trench by the trench wall method combined to image analysis (Bischetti et al., 2009; Hales et al., 2009). The method consists in cleaning the trench wall from all organic materials different from roots, putting a frame $0.3 \times 0.3 \mathrm{~m}$ as reference, and taking a series of images to obtain a vertical profile; to increase the contrast between soil and roots the trench wall were wetted and a great care was given to the scene illumination. Images were then rectified to correct geometrical deformations through a specific software (GIMP 2 www.gimp.org) and roots diameter and position were measured through manual digitalization of each root using GIS software (MapWindow 4.6 ww.mapwindow.org).

\section{Result}

\section{Root resistance}

Roots sampled at the different sites have been tested in terms of tensile resistance, obtaining a number of valid tests between 40 and 56 for each site. Statistics of tensile tests summarized in Table 2 show that the mean tensile resistance values resulted comparable between the three sites $(36,98 \mathrm{~N}$ for abandoned chestnut coppice in watershed; $34,53 \mathrm{~N}$ for managed chestnut coppice and 40,85 $\mathrm{N}$ for abandoned chestnut coppice on slope).

As force values $(F)$ depends on root diameter $(d)$ a regression $F-d$ relationship has been obtained and, in agreement with what already found by other studies (e.g. Vergani et al., 2012), this is a power - law type:

$$
F=a d^{b}
$$

Regression parameters are reported in Table 2 and show that the relationship is strong and highly significant in all the cases.

To verify a possible influence of over-aging and/or topography on root resistance, force-diameter data from the three different sites have been analysed by ANCOVA using diameter as a covariate. Results (Table 3) indicate that no significant difference can be detected between the resistance of roots sampled in the three sites.

As a consequence, it was possible to build a $F$ - $d$ relationship by using all values in a single power - law regression (Figure 3):

$$
F=10,80 d^{1,57}
$$

\section{Root density distribution}

The general trend in all sites, as expected, is a decrease in root density with depth, although in site $\mathrm{C}$ such a trend is less clear compared to sites $\mathrm{A}$ and $\mathrm{B}$.

Table 2. Statistics of tensile tests and parameters of regression $F-d$ power - law relationship

\begin{tabular}{lccc} 
Site valid tests (\#) & Site A & Site B & Site C \\
& 48 & 40 & 56 \\
Diameter (mm) & & & \\
$\quad$ Aver. & 1,87 & 1,88 & 2,05 \\
$\quad$ Max & 6,8 & 5,46 & 4,96 \\
$\quad$ Min & 0,6 & 0,55 & 0,34 \\
Force at rupture (N) & & & \\
Aver. & 36,98 & 34,53 & 40,85 \\
Max & 200,15 & 230,19 & 150,64 \\
Min & 3,83 & 4,67 & 2,49 \\
\hline $\mathrm{a}^{1}$ & 11,4 & 10,47 & 10,6 \\
$\mathrm{~b}^{1}$ & 1,56 & 1,52 & 1,6 \\
\hline $\mathrm{R}^{2}$ & 0,87 & 0,82 & 0,93 \\
$\mathrm{p}$ & $<0,001$ & $<0,001$ & $<0,001$ \\
\hline $\mathrm{F}$ & 297,9 & 176,5 & 717 \\
\hline
\end{tabular}

${ }^{1}$ regression parameters of Equation 2.

Table 3. Results of ANCOVA between $F-d$ series; Test $\mathrm{L}$ is Levene test for homoschedasticity, Test KS is Kolmogorov-Smirnov test for normality, Test Par. is the parallelism test and Test Int. is the intercept test.

\begin{tabular}{lllll} 
Comparison & Test $\mathrm{L}$ & Test KS & Test Par. & Test Int. \\
A-B & $\mathrm{F}_{1 ; 84}=0,42$ & p-value $=0.89$ & $\mathrm{~F}_{1 ; 84}=467$ & $\mathrm{~F}_{1 ; 85}=472$ \\
& $\operatorname{Pr}(>\mathrm{F})=0,52$ & & $\operatorname{Pr}(>\mathrm{F})<0,001$ & $\operatorname{Pr}(>\mathrm{F})<0,001$ \\
A-C & $\mathrm{F}_{1 ; 102}=1,88$ & p-value $=0,70$ & $\mathrm{~F}_{1 ; 100}=960$ & $\mathrm{~F}_{1 ; 101}=968$ \\
& $\operatorname{Pr}(>\mathrm{F})=0,17$ & & $\operatorname{Pr}(>\mathrm{F})<0.001$ & $\operatorname{Pr}(>\mathrm{F})<0.001$ \\
\hline B-C & $\mathrm{F}_{1 ; 94}=3,59$ & p-value $=0,76$ & $\mathrm{~F}_{1 ; 92}=802$ & $\mathrm{~F}_{1 ; 93}=807$ \\
& $\operatorname{Pr}(>\mathrm{F})=0,06$ & & $\operatorname{Pr}(>\mathrm{F})<0.001$ & $\operatorname{Pr}(>\mathrm{F})<0.001$ \\
\hline
\end{tabular}

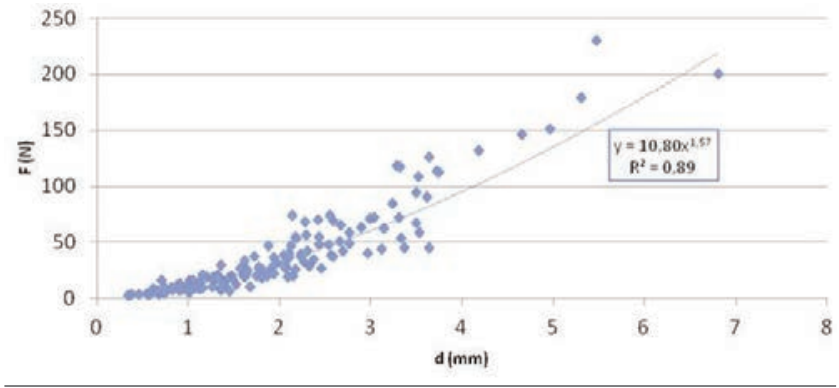

Figure 3. Force - diameter power - law relationship valid for all sites $\left(\mathbf{R}^{2}\right.$ $=0,89$ ). 
Rooting depth corresponds approximately to the pedologically active layers and then is shallower in the case of site B. Despite this difference, however, the total number of roots per unit width of soil is greater in the case of site B compared to sites A and C (2745, 2533 and 1878 roots/m, respectively). An important difference can also be noted in terms of size distribution (Figure 4); in site A and B, 1-2 mm class dramatically prevails on other size classes at all depths (between $70 \%$ and $80 \%$ ), whereas in site $\mathrm{C}$ it represents only a little more than a half (between $40 \%$ and $60 \%$ ).

\section{Additional root cohesion}

Additional root cohesion values were calculated at different depths in each site basing on root $F$ - $d$ relationship (Equation 2) and root density distributions, as previously introduced.

$c_{r}$ values range between $5-25 \mathrm{kPa}$ in shallower layers $(10-20 \mathrm{~cm})$ to $5-10 \mathrm{kPa}$ in deeper layers $(50-90 \mathrm{~cm})$. Looking $c_{r}$ distribution with depth for the three sites (Figure 5), it can be noted that they agree quite well with root density and size distributions as expected.

\section{Slope stability}

Slope stability at the three sites have been estimated by the infinite slope model implemented by Equation 1, fixing the potential shear surface at a depth of $0,9 \mathrm{~m}$. In sites $\mathrm{A}$ and $\mathrm{C}$, in fact, it is at such depth that shearing is most likely to occur, being a significant change in soil horizons (from A to B) and roots density.

In general it is worth to note that under the General Limit Equilibrium framework, it is evident that without any contribution from vegetation sites $A$ and $C$ would be intrinsically unstable as in cohesionless soils the FoS in dry conditions simply reduces to the ratio between the friction angle and the slope inclination.

Equation 1 was firstly applied to site $\mathrm{A}$ and $\mathrm{C}$ with different soil saturation levels to estimate the present level of stability (Figure 6). It can be observed from FoS curves that site A become unstable when saturation level exceeds $70 \%$ and at risk of instability also for smaller values. Site $\mathrm{C}$ can be considered stable for all level of saturation except for values higher than $60-70 \%$ for which it is moderately stable.

Due to uncertainty and space variability of $c_{r}$ values, equation 1 was solved also combining site $\mathrm{A}$ with $c_{r}$ profile of site $\mathrm{C}$ and vice-versa. The results show that in both cases, FoS values are between the actual ones and nearly always greater than 1,0 (except for fully a saturated condition in site A).

\section{Discussion}

The results of tensile tests indicate that root sampled at the three considered sites are not significantly different in terms of tensile resistance. The over-aging of coppice chestnut and/or the topography, as consequence, do not affect root tensile resistance, confirming that the main drivers of such a property are diameter and species, as found by previous researches (e.g. Genet et al., 2005; Vergani et al., 2012).

Root density and size distribution, on the contrary, showed several differences. First in sites $\mathrm{A}$ and $\mathrm{C}$ (over-aged forests) the rooting depth is higher than site $\mathrm{B}$, where forest is managed (although at the end of its rotation). In principle, this could be explained by the charactersitic of chestnut stools to renew completely their root system at each coppicing operation (Bedeneau e Pagés, 1984) because this could keep roots shallower. Despite steepness, however, in sites A and C present an accumulation of soil, likely to arrive from the upper part of hillslope, and this makes roots deepening easier than in site B. Steepness itself, moreover, requires a deeper rooting to balance overturning moments.

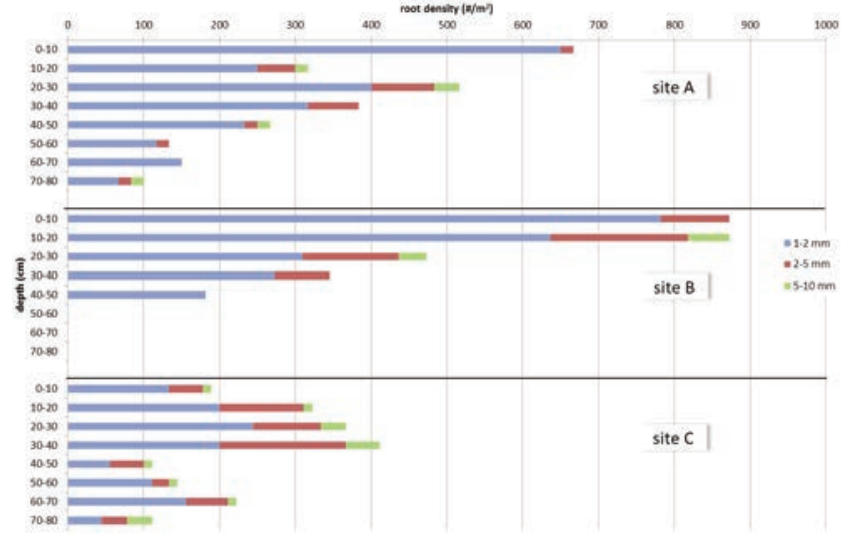

Figure 4. the distribution of root diameters resulted quite different for the three investigated sites in terms of maximum depth, number at different depth and size; in site $B$ roots are shallower and denser with respect to other sites; in site $\mathrm{C}$ roots are about half compared to other sites and fine roots don't prevail on thicker classes.).

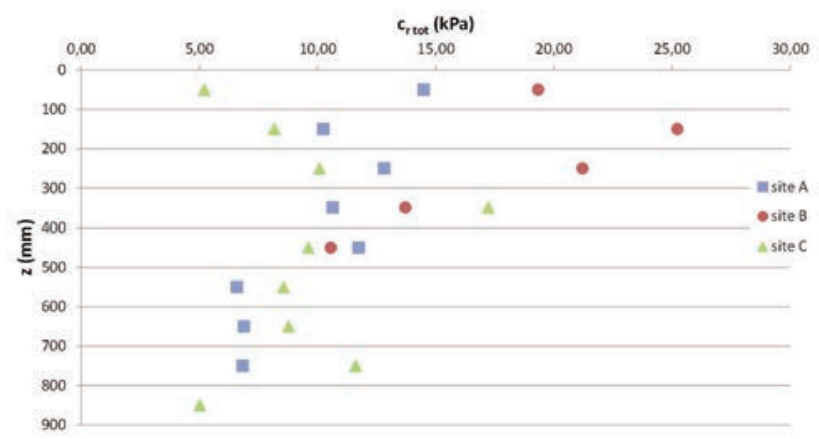

Figure 5. $c_{r}$ values distributions with depth at the three considered sites show that the contribution of roots can be significant also in depth.

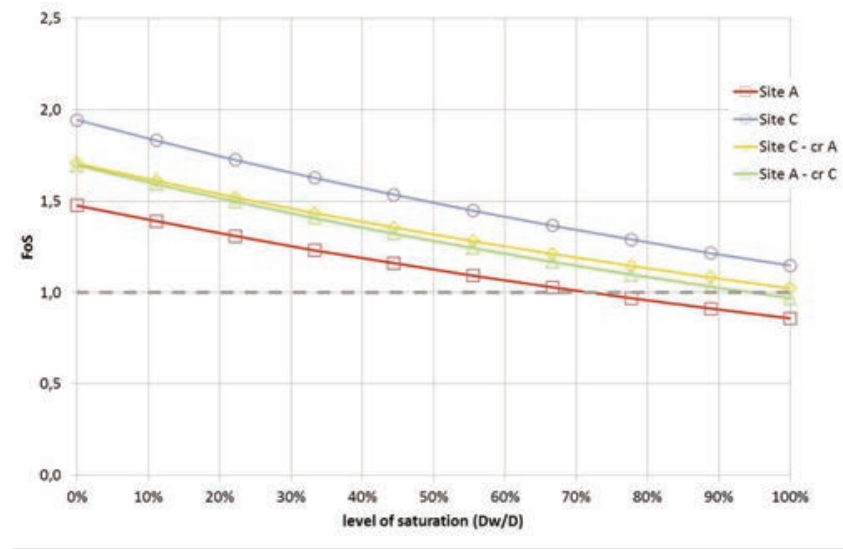

Figure 6. FoS values at sites $\mathrm{A}$ and $\mathrm{C}$ for increasing levels of saturation showing the level of instability. 


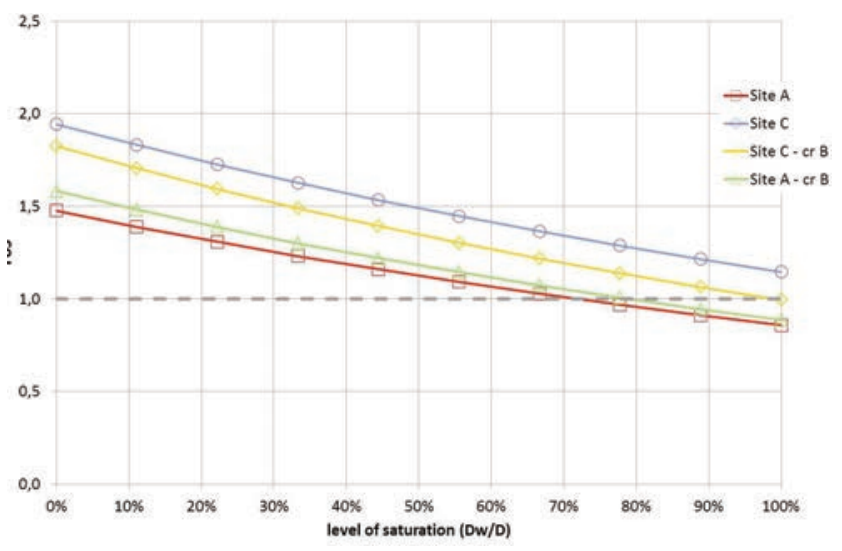

Figure 7. Comparison of FoS at sites $\mathrm{A}$ and $\mathrm{C}$ by adopting original cr values and values obtained from site $B$.

Besides rooting depth, a second point concerns the size distribution that is fairly similar in site $\mathrm{A}$ and $\mathrm{B}$; the total number of roots is approximately the same, as well as the proportion of fine roots (1-2 mm class). On the contrary, in site $\mathrm{C}$ total root number is $75 \%$ of those at site A and, more relevant, fine roots are only a half of the total.

Such findings, which can have important implication on root cohesion, can be explained looking at the site characteristics. At site $\mathrm{C}$, in fact, stools are sparser and dead stools are more in comparison to sites $A$ and $B$ (Table 1).

In any case, taking site B as a reference for managed condition, $c_{r}$ distribution estimated at site B was applied to sites A and C (keeping shear plane depth at $0.9 \mathrm{~m}$ ) for evaluating possible consequences of a restart in managing over-aged chestnut forests on steep slopes. Basing on the unfortunately scarce literature, in fact, a continuous renewal of root system consequent to coppicing could change root size distribution (Bedeneau e Pages, 1984; Aymard e Fredon, 1986; Bagnara e Salbitano, 1998).

The results (Figure 7) basically show a reduction in slope stability for site $\mathrm{C}$, that for higher level of saturation could be critical, whereas in the case of site A changes are negligible.

\section{Concluding remarks}

This paper has shown that over-aged coppiced sweet chestnut forests, as well as managed ones of course, are fundamental in guarantee hillslope stability in those territories where steepness and poor geotechnical properties of soil make hillslopes intrinsically unstable.

The results of this study, in particular, show that root tensile resistance of single roots seems to do not be affected by over-aging, whereas on the contrary, root density and size distribution can be.

By estimating hillslope stability including overload and additional cohesion due to forest, it has be shown that in the case of steep and cohesionless terrains covered by over-aged chestnut forests, instability phenomena can be triggered by high level of soil saturation when steepness exceeds $35^{\circ}$. For less extreme case, instead, chestnut forests, although over-aged, are fundamental in guarantying stability. As over-aged coppiced forests, however, are subject to extensive overturning phenomena which could evolve in more severe phenomena, coppicing operations should be incentivized giving a higher priority to steeper hillsopes.

\section{References}

Abdi E:, Majnounian B., Genet M., Rahimi H. (2010) Quantifying the effeects of root reinforcement of Persian Ironwood (Parrotia persica) on slope stability; a case study: Hillslope of Hyrcanian forests, northern Iran. Ecol. Eng. 36:1409-1416

Aymard M., Fredon J-J (1986) Etude de realtion entre une racine et les rejets de la souche chez Castanea sativa Miller. Ann. Sci. For., 43,3,351-364.

Bagnara L., Salbitano F., 1998. Struttura delle ceppaie e dei sistemi radicali in cedui di faggio sui monti Sibillini. Sherwood, 30: 31-34

Bedeneau M., Pagès L. (1984) Etudes des cernes d'accroissement ligneux du système racinaire d'arbres traits en tallis. Ann. Sci. For., 41, 59-68.

Bischetti G.B., Bonfanti F., Greppi M. (2003) Misura della resistenza a trazione delle radici: apparato sperimentale e metodologia di analisi. Quad. Idronomia Mont 241

Bischetti G.B., Simonato T., Chiaradia E.A. (2004) Valutazione del contributo degli apparati radicali nell'analisi di stabilità ei movimenti franosi superficiali, Riv. Ing. Agr., 3, 33-40.

Bischetti, G.B., Chiaradia, E.A., Epis, T., Morlotti, E. (2009) Root Cohesion of forest spe-cies in the Italian Alps, Plant and Soil. DOI 10.1007/s11104-009-9941-0.

Casagrande A. 1948. Classification and Identification of Soils. Transactions ASCE. p. 901.

Del Favero R. (ed.). 2002. I tipi forestali nella regione Lombardia, Regione Lombardia, Cierre edizioni, Verona (Italy), 506 pp.

Genet M., Stokes A., Salin F., Mickovski S.B., Fourcaud T., Dumail J-F, van Beek R. 2005, The influence of cellulose content on tensile strength in tree roots, Plant and Soil, 278:1-9

Genet M., Stokes A., Fourcaud T., Norris J. (2010) The influence of plant diversity on slope stability in a moist evergreen deciduos forest. Ecol. Eng. 36:365-275

Hammond C., Hall D., Miller S., Swetik P. (1992) Level I Stability Analysis (LISA) Documentation for Version 2.0. United States Department of Agriculture, Intermountain Research Station, General Technical Report INT-285.

Hales T.C., Ford C.R., Hwang T., Vose J.M., Band L.E. (2009) Topographic and ecologic controls on root reinforcement. J. Geophys. Res. 114, F03013.

Ji J., Kokutse N., Genet M., Forcaud T., Zhang Z. (2012) Effect of spatial variation of tree root characteristics on slope stability. A case study on Black Locust (Robinia pseudoacacia) and Arborvitae (Platycladus orientalis) stand on the Loess Plateau. China. Catena. 92:139-154

Mao R., Zeng D.-H., Li L.-J. (2012) Engineering ecological protection against landslides in diverse mountain forests: Choosing cohesion models. Ecol. Eng. 45:52-69

Meyer Fh., Gottsche D. (1970) Distribution of root tips and tender roots of beech. In: Ellenberg H. (ed) Ecological studies. Analysis and synthesis. Vol. 2 Springer - Verlag. Berlin. pp. 47-52

Motta R., Haudemand J.C. (2000) Protective forests and sylvicultural stability: an example of planning in the Aosta Valley. Mt Res Dev 20: 180-187

Pollen N., Simon A. (2005) Estimating the mechanical effect of riparian vegetation on streambank stability using fiber bundle model. Water Resour. Res. 41:W07025

Roering J.J, Schmidt K.M., Stock J.D. et al. (2003) Shallow landsliding, root reinforcement, and the spatial distribution of trees in the Oregon Coast Range. Can. Geotech. J. 40:237-253

Sakals M.E., Sidle R.C: (2004) A spatial and temporal model of root cohesion in forest soil. Can. J. For. Res. 34:950-958 
Schwarz M, Cohen D, Or D. 2010. Root-soil mechanical interactions during pullout and failure of root bundles, J.Geophys. Res.: 21562202.

Sidle RC, Ochiai H. 2006. Landslides: Processes, prediction, and land use. Washington, DC: American Geophysical Union.

Vergani C., Chiaradia E.A., Bischetti G.B. (2012) Variability in the tensile resi stance in Alpine forest tree species. Ecol. Eng. http://dx.doi.org/10.1016/j.ecoleng.2012.04.036

Waldron, L.J. (1977) The shear resistance of root-permeated homoge- neous and stratified soil, Doil Science Society of America Journal, $41,843-849$.

$\mathrm{Wu}, \mathrm{T}$. H. (2013). Root reinforcement of soil: Review of analytical models, test results, and applications to design. Canadian Geotechnical Journal, 50(3), 259-274

Wu, T.H. McKinnel, W.P., Swanston, D.N. (1979) Strength of tree roots and landslides on prince of Wales Island, Alaska, Canadian Geotechnical Journal, 16, 19-33. 